\title{
PENERAPAN PENDEKATAN OPEN-ENDED UNTUK MENINGKATKAN KEMAMPUAN PEMECAHAN MASALAH MATEMATIK SISWA MTS
}

\author{
M. Najiyuloh Assabanny ${ }^{1}$, Iyan Sopian ${ }^{2}$, Heris Hendriana ${ }^{3}$, Luvy Sylviana Zanthy ${ }^{4}$ \\ 1, 2,3,4 IKIP Siliwangi Bandung, Jalan Terusan Jenderal Sudirman, Cimahi Indonesia \\ ${ }^{1}$ asysyabanynajiyyullah@gmail.com ${ }^{2}$ iyan10sopian@gmail.com, ${ }^{3}$ herishen@ikipsiliwangi.ac.id, \\ ${ }^{4}$ zanthyluvy@ikipsiliwangi.ac.id
}

\begin{abstract}
This research aims to examine the differences in the improvement of mathematical problem-solving ab ilities of MTs students with an open-ended approach and conventional learning. In this research the res earchers applied quasi-experimental method, where the samples in this research are students of class V II MTs in Cianjur district and take the subject of students of MTs Tanwiriyyah class VII I a total of 41 students as experimental class who get the learning treatment using the approach Open-Ended and clas s VII H totaling 40 students as control class that get conventional learning. In this study the instrument that applied the test instrument of the problem-solving ability of mathematics as much as 4 item. The $r$ esult of N-Gain data analysis using t' test shows students' mathematical problem-solving ability of the experimental class is better than the control class.
\end{abstract}

Keywords: Problem Solving, Open Ended

\begin{abstract}
Abstrak
Penelitian ini bertujuan untuk menganalisa perbedaan peningkatan kemampuan pemecahan masalah matematik siswa MTs dengan pembelajaran yang menggunakan pendekatan open-Ended serta pembelajaran biasa. Pada penelitian ini peneliti menerapkan metode kuasi eksperimen, dalam penelitian ini yang menjadi populasi yaitu peserta didik kelas VII MTs se-kebupaten Cianjur dan diambil subjek sampel siswa MTs Tanwiriyyah kelas VII I sejumlah 41 peserta didik sebagai kelas eksperimen yang mendapatkan perlakuan pembelajaran menggunakan pendekatan Open-Ended dan kelas VII H yang berjumlah 40 siswa sebagai kelas kontrol yang mendapatkan pembelajaran biasa. Pada penelitian ini intrumen yang diterapkan yaitu instrument tes kemampuan pemecahan masalah matematik sebanyak 4 butir soal. Hasil analisis data N-Gain yang mengunakan Uji t' menunjukan kemampuan pemecahan masalah matematik siswa kelas eksperimen lebih baik dari pada kelas kontrol.
\end{abstract}

Kata Kunci: Pemecahan Masalah, Open-Ended

How to cite: Assabanny, M. N., Sopian, I., Hendriana, H., \& Zanthy, L. S. (2018). Penerapan Pendekatan Open-Ended untuk Meningkatkan Kemampuan Pemecahan Masalah Matematik Siswa MTs. JPMI - Jurnal Pembelajaran Matematika Inovatif, 1 (4), 637-646.

\section{PENDAHULUAN}

Pembelajaran matematika penting untuk diajarkan kepada peserta didik baik sekolah dasar bahkan perguruan tinggi. Menurut Zanthy (2016) yang mendasari matematika perlu diajarkan karena banyak masalah dalam kehidupan yang dapat disajikan melalui model matematika. Pendapat tersebut sejalan dengan Cockcroft (Andriani, Ikhsan, \& Anshari, 2016), matematika perlu diajarkan kepada siswa karena matematika : (1) selalu digunakan dalam segala kehidupan; (2) menjadi media komunikasi yang kuat dan jelas; (3) Digunakan untuk menginformasikan dalam berbagai cara; (4) Keterkaitan antara matematika dengan study lainnya; (5) memotivasi mencari penyelesaian dari permasalahan yang menantang. 
Pada pembelajaran matematika siswa diharapkan mampu untuk memecahkan suatu permasalahan yang meliputi kemampuan pemecahan masalah sebagaimana tertuang dalam indikator kemampuan pemecahan masalah menurut Sumarmo (Husna, Ikhsan, \& Fatimah, 2013) sebagai berikut:

(a) Mengidentifikasi unsur yang diketahui, ditanyakan, dan kecukupan unsur;

(b) Membuat model matematika;

(c) Mengimplementasikan strategi pemecahan masalah di dalam/luar matematika;

(d) Menginterpretasikan hasil;

(e) Menyelesaikan model matematika dan masalah nyata.

Jika dipandang dari aspek kurikulum kemampuan pemecahan masalah merupakan tujuan dalam proses belajar mengjar di sekolah. Sejalan dengan itu, Branca (Syaiful.dkk, 2011) mengemukakan bahwa kemampuan pemecahan masalah dianggap penting karena: (1) Kemampuan pemecahan sebagai jantungnya matematika; (2) Proses pokok dalam kurikulum matematika yakni metode, prosedur dan strategi terdapat pada kemampuan pemecahan masalah, dan (3) Pemecahan masalah adalah pondasi dalam proses kegiatan belajar mengjar mata pelajaran matematika.

Fakta di lapangan menunjukan bahwa kemampuan pemecahan masalah yang diajarkan di sekolah dalam pembelajaran matematika di SMP masih cukup rendah. Sejalan dengan penelitian yang dilakukan oleh Minarni (2012) pada suatu sekolah SMP di Kota Bandung, menunjukkan kemampuan pemecahan masalah matematik siswa dinilai rendah, dengan perhitungan rata-rata memperoleh skor 39 dari 100 .

Berdasarkan fakta diatas, muncul pertanyaan metode, strategi atau pendektan apa yang mampu mengatasi permasalahan diatas dalam upaya meningkatkan kemampuan pemecahan masalah. Alternatif solusi yang mungkin digunakan adalah menggunakan pendekatan open-ended. Pendektan open-ended merupakan pembelajaran yang tersaji suatu permasalahan yang mempunyai cara atau penyelesaian yang benar tidak hanya satu. Dengan demikian, pendekatan open-ended mampu memberi kesempatan kepada peserta didik untuk memperoleh pengetahuan, menemukan, mengenali, dan memecahkan masalah dengan beberapa teknik.

Pendekatan open-ended mempunyai tujuan membantu pengembangan kreatifitas serta pemikiran matematika siswa dalam pembelajaran melalui problem solving. Suherman (Wulandari \& Mashuri, 2014) juga mengungkapkan bahwa pendekatan open-ended memberikan suatu kesempatan peserta didik menginvestigasi berbagai strategi dan cara menyelesaikan suatu masalah yang dapat mengembangkan kemampuan pemecahan masalah matematik siswa.

Berdasarkan paparan permasalahan diatas, maka peneliti bermaksud untuk melakukan penelitian dengan judul "Penerapan Pendekatan Open-Ended untuk Meningkatkan Kemampuan Pemecahan Masalah Matematik Siswa MTs". Adapun rumusan masalah dalam penelitian ini yaitu :

1. Apakah pencapaian kemampuan pemecahan masalah matematis siswa yang pembelajarannya menggunakan pendekatan open-ended lebih baik daripada yang menggunakan pembelajaran biasa?

2. Apakah peningkatan kemampuan pemecahan masalah matematis siswa yang pembelajarannya menggunakan pendekatan open-ended lebih baik daripada yang menggunakan pembelajaran biasa? 


\section{METODE}

Penelitian ini menerapkan metode kuasi eksperimen. Populasi dalam penelitian ini yakni seluruh siswa kelas VII MTs se-kebupaten Cianjur dan diambil subjek dengan sampel siswa MTs Tanwiriyyah kelas VII I esbagai kelas eksperimen mendapatkan perlakuan pembelajaran menggunakan pendekatan Open-Ended sejumlah 41 siswa. Adapun kelas kontrol yang mendapatkan pembelajaran biasa adalah kelas VII H dengan jumlah 40 siswa.

Desain pada penelitian ini sebagaimana dipaparkan oleh Ruseffendi (2005) adalah sebagai berikut:

$\begin{array}{lll}0 & \mathrm{X} & 0\end{array}$

$0 \quad 0$

Keterangan :

$0=$ Pretest $=$ postes kemampuan pemecahan masalah matematik

$\mathrm{X}=$ Pembelajaran yang menggunakan pendekatan Open-Ended

....... = sampel yang diambil tidak secara acak

Sejunlah 4 butir soal uraian kemampuan pemecahan masalah matematik yang dijadikan intrumen tes pada penelitian ini serta telah divaliditas.

\section{HASIL DAN PEMBAHASAN}

\section{Hasil}

Pada proses analisis data nilai pretes, nilai postes serta N-Gain menggunakan bantuan software SPSS 22. Hasil uji normalitas hasil pretes terlihat pada table 1 berikut.

Tabel 1. Uji Normalitas Data Pretes

\begin{tabular}{|c|c|c|c|c|}
\hline Kelas & $\bar{x}$ & $\mathbf{N}$ & Sig. & Interpretasi \\
\hline Eksperimen & 13.71 & 41 & 0,000 & Tidak berdistribusi normal \\
\hline Control & 13.60 & 40 & 0,001 & Tidak berdistribusi normal \\
\hline
\end{tabular}

Berdasarkan uji normalitas, kelas eksperimen diketahui nilai signifikansinya adalah 0,000 dan kelas kontrol adalah 0,001. karena keduanya memiliki nilai signifikansi kurang dari 0,05 maka kedua data tersebut tidak berdistribusi normal. Selanjutnya dilakukan Uji Mann Whitney. Hasil Uji Mann Whitney nampak pada tabel 2 berikut.

Tabel 2. Uji Mann-Whitney

\begin{tabular}{cc}
\hline & Pretes \\
\hline Mann-Whitney U & 778,000 \\
Wilcoxon W & 1639,000 \\
Z & $-0,416$ \\
Asymp. Sig. (2-tailed) & 0,677 \\
\hline
\end{tabular}

Berdasarkan hasil perhitungan Mann-Whitney nilai signifikansinya 0,677 ( Sig > 0,05 maka H0 diterima). Sehingga secara signifikan kemampuan awal pemecahan masalah matematik pada kelas eksperimen dan kelas kontrol tidak memilki perbedaan. 
Setelah pembelajaran dilakukan pada kelas eksperimen dan kelas kontrol kemudian dilakukan postes. Data hasil postes selanjutnya diolah dan diuji normalitasnya. Berikut hasil uji normalitas data hasil postes.

Tabel 3. Uji Normalitas Data Postes

\begin{tabular}{lcccc}
\hline Kelas & $\overline{\boldsymbol{x}}$ & $\mathbf{N}$ & Sig. & Interpretasi \\
\hline Eksperimen & 36,80 & 41 & 0,072 & Berdistribusi normal \\
kontrol & 29,95 & 40 & 0,153 & Berdistribusi normal \\
\hline
\end{tabular}

Berdasarkan uji normalitas, terlihat nilai signifikansi kelas eksperimen dan kelas kontrol masing-masing 0,072 dan 0,153. Karena masing-masing kelas memiliki nilai signifikansi lebih dari 0,05 maka keduanya berdistribusi normal, sehingga dilanjutkan dengan uji homogenitas. Hasil uji homogenitas nampak pada tabel 4 berikut.

Tabel 4. Uji Homogenitas Data Postes

\begin{tabular}{cccc}
\hline Levene Statistic & df1 & df2 & Sig. \\
\hline 18,860 & 1 & 76 & 0,000 \\
\hline
\end{tabular}

Pada tabel 4, terlihat nilai signifikansinya adalah 0,000. Karena sig. $<0,05$ sehingga data kedua kelas tersebut tidak homogen. Karena data tersebut tidak homogen maka pengujian selanjutnya adalah uji $t$ '. Hasil uji t' nampak pada tabel 5 berikut.

Tabel 5. Uji t’ Data Postes

\begin{tabular}{lcccc}
\hline & & T & Df & Sig. (2-tailed) \\
\hline Postes & Equal Variances not assumed & 4,264 & 66,541 & 0,000 \\
\hline
\end{tabular}

Berdasarkan penghitungan Uji t', diketahui signifikansinya adalah 0,000. Karena $\operatorname{sig}<$ 0,000 maka kemampuan pemecahan masalah matematik antara kelas eksperimen dengan kelas kontrol terdapat perbedaan.

Tahapan pengujian pencapaian kemampuan pemecahan masalah matematik siswa kelas eksperimen dan kontrol untuk mengukur peningkatan kemampuan pemecahan masalah matetmatik siswa pada kelas tersebut telah dilaksanakan, langkah selanjutnya melakukan pengujian gain ternormalisasi menggunakan rumus berdasarkan Meltzer (Istianah, 2013) dan untuk menginterpretasikan data tersebut menggunakan kriteria indeks Gain ternormalisasi berdasarkan Hake (Istianah, 2013).

Setelah diketahui data Gain, selanjutnya dilakukan uji normalitas data Gain. Berikut hasil uji normalitas data Gain.

Tabel 6. Uji Normalitas Data Gain

\begin{tabular}{lccll}
\hline Kelas & $\overline{\boldsymbol{x}}$ & $\mathbf{N}$ & Sig. & Interpretasi \\
\hline Eksperimen & 0,50313 & 41 & 0,053 & Berdistribusi normal \\
kontrol & 0,35170 & 40 & 0,200 & Berdistribusi normal \\
\hline
\end{tabular}

Berdasarkan uji normalitas, diketahui nilai signifikansi kelas eksperimen 0,053 dan nilai signifikansi kelas kontrol 0,200. karena kedua kelas tersebut memiliki nilai signifikansi lebih dari 0,05 maka kedua data tersebut tidak berdistribusi normal. Karena data tersebut berdistribusi 
normal, maka langkah selanjutnya dilakukan pengujian homogenitas. Hasil uji homogenitas dapat terlihat pada tabel 7 berikut ini.

Tabel 7. Uji Homogenitas Data Gain

\begin{tabular}{cccc}
\hline Levene Statistic & df1 & df2 & Sig. \\
\hline 16,044 & 1 & 79 & 0,000 \\
\hline
\end{tabular}

Pada tabel 7, diketahui nilai signifikansinya adalah 0,000. Karena sig. $<0,05$ sehingga kelas eksperimen dan kelas kontrol berasal dari populasi dengan varians yang berbeda ( tidak homogen). Karena data tersebut tidak homogen maka pengujian selanjutnya adalah uji t'. Hasil uji t` dapat dilihat pada tabel 8 berikut.

Tabel 9. Uji t’ Data Gain

\begin{tabular}{ccccc}
\hline & & T & Df & Sig. (2-tailed) \\
\hline Postes & Equal Variances not assumed & 4,519 & 69,008 & 0,000 \\
\hline
\end{tabular}

Berdasarkan penghitungan Uji $t^{\prime}$, diketahui nilai signifikansinya 0,000 . Karena sig $<0,000$ Sehingga dari hasil pengolahan data nilai gain di atas dapat terlihat bahwa peningkatan dan pencapaian kemampuan pemecahan masalah matematik siswa kelas eksperimen lebih baik daripada kelas kontrol.

\section{Pembahasan}

Berdasarkan analisis kemampuan awal siswa yang dilihat dari perolehan skor pretes masingmasing siswa pada kedua kelas tersebut menunjukan tidak terdapat perbedaan yang signifikan pada kemampuan pemecahan masalah matematik antara kelas eksperimen dengan kelas kontrol. Kemudian kedua kelas tersebut diberikan pembelajaran dengan perlakuan yang berbeda, untuk kelas eksperimen diberikan pembelajaran dengan menggunakan pendekatan open-ended sedangkan kelas kontrol dengan pembelajaran biasa.

Pada tes awal siswa tidak terbiasa dengan soal pemecahan masalah, ini ditunjukan ketika siswa diberikan pretes, Siswa cenderung kebingungan untuk memulai langkah penyelesaiannya. Yang disebabkan oleh ketidakbiasaan siswa mengerjakan soal-soal yang prosedur penyelesaiannya hanya menghitung dan mencari jawaban sesuai rumus yang ditentukan. Kemampuan pemecahan masalah mengarahkan siswa untuk terampil dalam penggunaan konsep, penyusunan strategi dan pelaksanaan proses untuk mencari alternatif penyelesaian masalah baru, tidak rutin dan tidak mudah untuk dicapai. Polya (Hendriana, Rohaeti, \& Sumarmo, 2017; Hidayat \& Sumarmo, 2013; Hidayat \& Sariningsih, 2018; Wahyu, 2014) mengatakan bahwa suatu usaha menemukan solusi mencapai tujuan yang sukar untuk dicapai merupakan definisi dari pemecahan masalah.

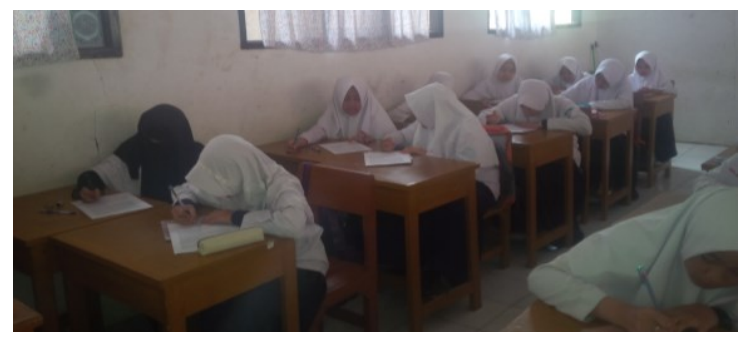

Gambar 1. Kegiatan Pretes 


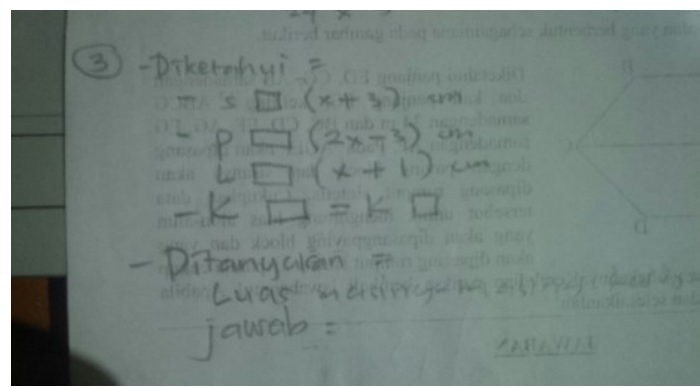

Gambar 2. Jawaban Pretes Siswa

Implementasi pendekatan open-ended dalam penelitian ini dilakukan dengan cara berkelompok. Guru mengkondisikan siswa menjadi beberapa kelompok yang setiap kelompoknya masing-masing terdiri dari 5-6 siswa. Pada tahap awal, siswa diberikan permasalahan yaitu berupa Lembar Kegiatan Siswa (LKS) tentang materi segiempat dan segitiga. Pada LKS tersebut tersaji beberapa soal berupa permasalahan terbuka. selanjutnya masalah tersebut didiskusikan secara berkelompok. Pada tahap ini secara berkelompok siswa dilatih untuk mengetahui informasi dengan baik, mencatat data yang diketahui dan ditanyakan , membuat model matematika dari permasalahan tersebut serta mencari strategi penyelesaian masalah yang relevan. Pada tahap selanjutnya, siswa diminta untuk mengeksplorasi dan menyelesaikan masalah tersebut secara berkelompok.

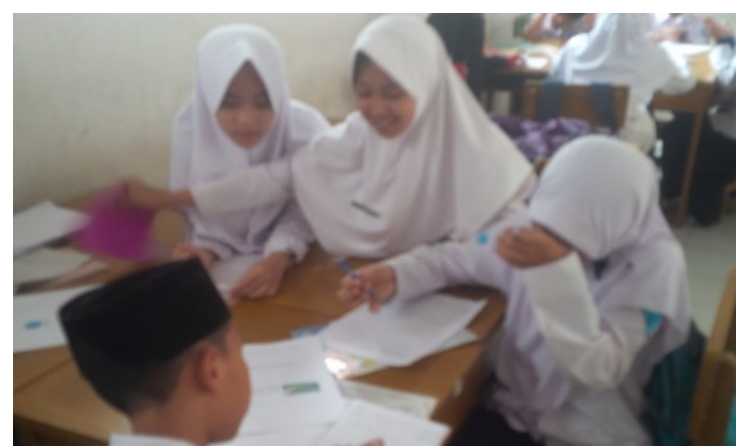

Gambar 3. Kegiatan Mengeksplorasi Masalah Terbuka Secara Berkelompok

Pada tahapan penyelesaian masalah siswa diharapkan mencari berbagai strategi serta menentukan alternatif jawaban karena dalam pendekatan open-ended siswa memungkinkan untuk menentukan strategi ataupun jawaban yang tepat tidak hanya satu. Hal ini diungkapkan oleh Shimada (Rahmawati \& Harta, 2014) bahwa pendekatan open-ended merupakan pendekatan pembelajaran yang menyajikan suatu permasalahan yang memiliki cara atau penyelesaian yang benar tidak hanya satu, bukan meminta siswa megarah pada satu jawaban benar melainkan lebih berfokus pada cara siswa untuk sampai pada penyelesaian masalah. Pada proses diskusi dan eksplorasi masalah guru membimbing dan memberikan kesempatan bagi siswa untuk bertanya tentang masalah tersebut. Bimbingan dari guru dibutuhkan agar siswa dapat memiliki motivasi serta kepercayaan terhadap diri sendiri sehingga siswa dapat turut aktif dalam pembelajaran matematika dan memahami permasalahan yang terdapat pada LKS. Selanjutnya tiap kelompok dipersilahkan untuk menyiapkan hasil kerja secara sistematis.

Kemudian pada tahap akhir pendekatan open-ended yaitu presentasi hasil diskusi. Pada tahapan ini, beberapa perwakilan kelompok akan dipilih oleh guru untuk mempresentasikan hasil diskusi kelompok di depan kelas. Siswa dituntut bertanggung jawab atas jawaban yang telah didiskusikan serta memandang secara objektif pendapat dari kelompok lain. Pada tahap ini, 
kelompok lain dipersilahkan untuk bertanya serta menanggapi hasil diskusi yang dipresentasikan oleh kelompok narasumber.

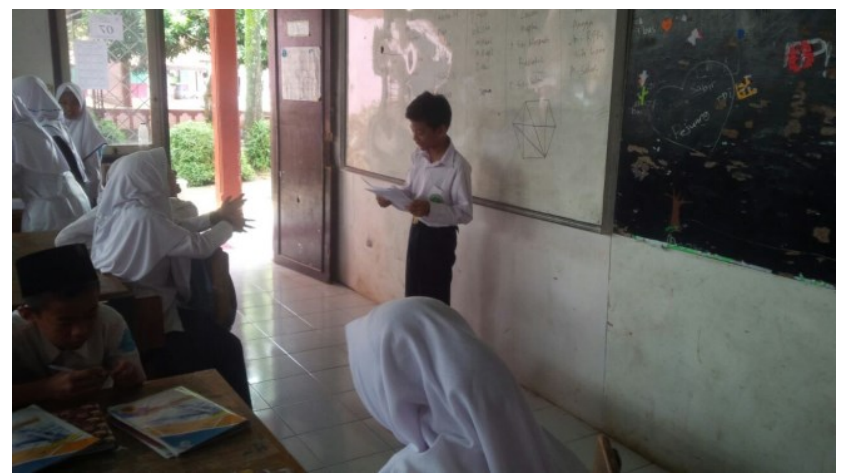

Gambar 4. Presentasi Hasil Diskusi oleh Perwakilan Kelompok

Setelah materi pembelajaran disampaikan, siswa diberikan tes akhir berupa soal postes kemampuan pemecahan masalah matematik.

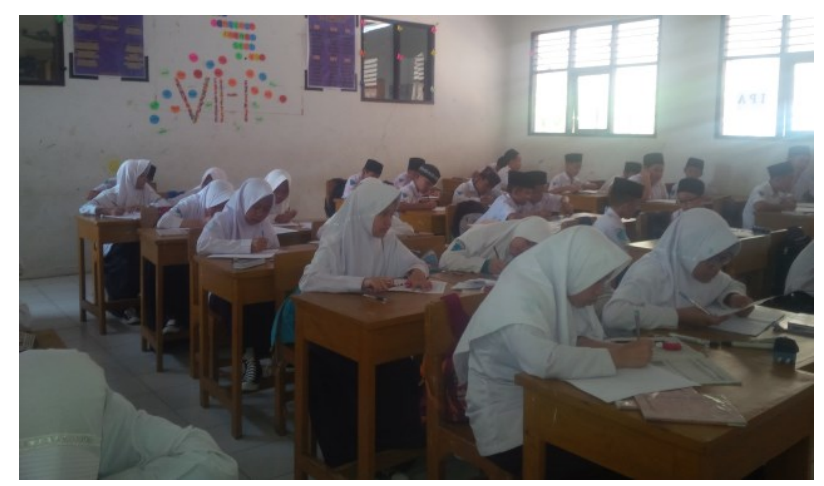

Gambar 5. Kegiatan Postes

Selanjutnya hasil postes dianalisis dan diberikan skor berdasarkan rubrik pemberian skor tes kemampuan pemecahan masalah matematik.

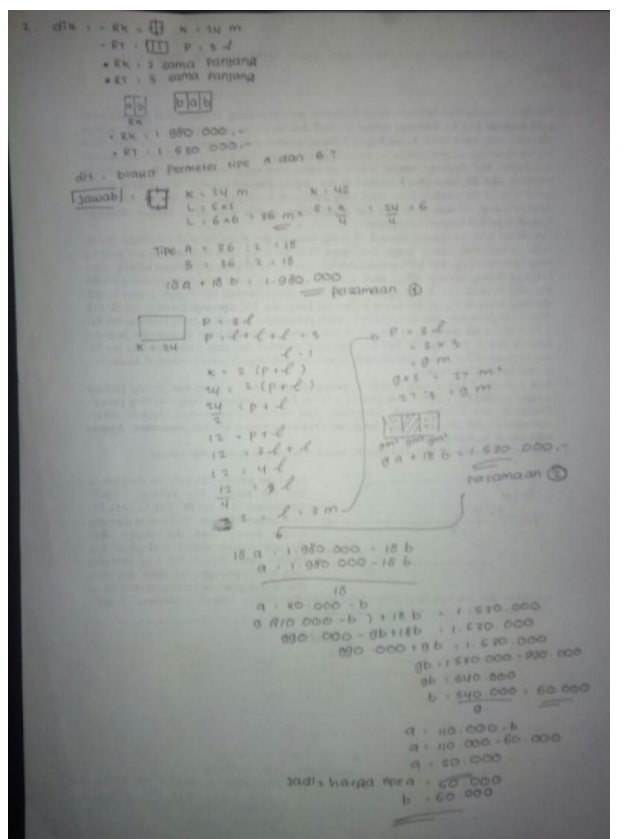

Gambar 6. Salah Satu Jawaban Siswa 
Kemudian hasil tes diolah dan dianalisis dengan berbantuan software SPSS 22. Berdasarkan hasil analisis data postes, diketahui bahwa terdapat berbedaan kemampuan pemecahan masalah matematik antara kedua kelas tersebut. Sedangkan hasil uji N-Gain dapat diketahui bahwa pencapaian dan peningkatan kemampuan pemecahan masalah matematik siswa kelas eksperimen lebih baik daripada kelas kontrol..

\section{KESIMPULAN}

Berdasarkan analisis data dan pembahasan, dapat disimpulkan bahwa pencapaian dan peningkatan kemampuan pemecahan masalah matematik siswa kelas eksperimen yang pembelajarannya menggunakan pendekatan open-ended lebih baik daripada kelas kontrol yang menggunakan pembelajaran biasa. Oleh karena itu, pendekatan open-ended direkomendasikan untuk digunakan dalam pembelajaran matematika pada topik-topik tertentu karena pendekatan ini mampu mengembangkan dan meningkatkan kemampuan pemecahan masalah matematik siswa.

\section{DAFTAR PUSTAKA}

Andriani, Ikhsan, M., \& Anshari, B. I. (2016). Peningkatan Kemampuan Pemahaman dan Motivasi Siswa SMP melalui Model Missouri Mathematics Project ( MMP ) dengan Menggunakan Game Matematika Online. Didaktik Matematika, 3, 55-63.

Hendriana, H., Rohaeti, E.E., Sumarmo, U. (2017). Hard Skills dan Soft Skills Matematik Siswa. Bandung: PT. Refika Aditama.

Hidayat, W., \& Sumarmo, U. (2013). Kemampuan Komunikasi dan Berpikir Logis Matematika serta Kemandirian Belajar. dalam Jurnal Delta-fi, 2(1).

Hidayat, W., \& Sariningsih, R. (2018). Kemampuan Pemecahan Masalah Matematis dan Adversity Quotient Siswa SMP Melalui Pembelajaran Open Ended. JNPM (Jurnal Nasional Pendidikan Matematika), 2(1), 109-118.

Husna, Ikhsan, M., \& Fatimah, S. (2013). Peningkatan Kemampuan Pemecahan Masalah dan Komunikasi Matematis Siswa SMP Melalui Model Pembelajaran Kooperatif Tipe Think Pair Share (TPS). Jurnal Peluang, 1(4), 81-92.

Istianah, E. (2013). Menigkatkan Kemampuan Berpikir Kritis dan Kreatif Matematik dengan Pendekatan Model Eliciting Activities (MEAS) Pada Siswa SMA. Infinity, 2(1), 43-54. https://doi.org/https://doi.org/10.22460/infinity.v2i1.23

Minarni, A. (2012). Pengaruh pembelajaran berbasis masalah terhadap kemampuan pemecahan masalah matematis. Prosiding, (November), 978-979.

Novtiar, C., \& Aripin, U. (2017). MENINGKATKAN KEMAMPUAN BERPIKIR KRITIS MATEMATIS DAN KEPERCAYAAN DIRI SISWA SMP MELALUI PENDEKATAN OPEN ENDED. PRISMA, 6(2).

Rahmawati, Y., \& Harta, I. (2014). Keefektifan pendekatan open-ended dan CTL ditinjau dari hasil belajar kognitif dan afektif. Jurnal Riset Pendidikan Matematika, 1(1), 113-126. 
https://doi.org/10.21831/jrpm.v1i1.2669

Ruseffendi, E. T. (2005). Dasar-Dasar Penelitian Pendidikan dan Bidang Non Eksakta Lainnya. Bandung: Tarsito.

Syaiful.dkk. (2011). Peningkatan Kemampuan Pemecahan Masalah Matematis SMP Melalui Pendekatan Pendidikan Matematika Realistik. Prosiding Seminar Nasional Penelitian Pendidikan Dan Penerapan MIPA Fakultas MIPA Universitas Negeri Yogyakarta, (1).

Wahyu, H. (2014). The Implementation of MEAs Instruction to Students' Mathematics Problem Solving and Connecting Ability. In Proceeding of International Conference on Research, Implementation and Education of Mathematics and Sciences 2014. Yogyakarta State University.

Wulandari, N., \& Mashuri. (2014). Keefektifan Pembelajaran CIRC dengan Pendekatan OpenEnded Terhadap Kemampuan Berpikir Kreatif Siswa Kelas-VIII Materi Kubus-Balok. Unnes Journal of Mathematics Education. https://doi.org/10.15294/ujme.v3i3.4489

Zanthy, L. S. (2016). Pengaruh Motivasi Belajar Ditinjau dari Latar Belakang Pilihan Jurusan Terhadap Kemampuan Berpikir Kritis Mahasiswa di STKIP Siliwangi Bandung. Teorema, 1(1). 
